\title{
Transfer of Escherichia Coli to Lemons Slices and Ice during Handling
}

\author{
Paul Dawson ${ }^{1}$, Inyee Han ${ }^{1}$, Ahmet Buyukyavuz ${ }^{1}$, Wesam Aljeddawi ${ }^{1}$, Rose Martinez-Dawson ${ }^{2}$, Rachel Downs ${ }^{1}$, \\ Delaney Riggs ${ }^{1}$, Carrrie Mattox ${ }^{1}$, Alejandro Kurtz ${ }^{1}$, Mary MacInnis ${ }^{1}$, Jacob Freeland ${ }^{1}$, Seth Garrison ${ }^{1}$, Taylor \\ May $^{1}$, James McClary ${ }^{1}$, Frank Monitto ${ }^{1}$, Trinh Nguyen $^{1}$, Kelly Polte ${ }^{1}$, Matthew Suffern ${ }^{1}$, Zachary Tanner ${ }^{1}$, \\ Alana Thurmond ${ }^{1} \&$ Virginia Ellis ${ }^{1}$ \\ ${ }^{1}$ Department of Food, Nutrition and Packaging Sciences, ${ }^{2}$ Department of Mathematical Sciences, Clemson \\ University, Clemson, SC 29634, USA \\ Correspondence: Paul Dawson, Depertment of Food, Nutrition and Packaging Sciences, Clemson University, \\ Clemson, SC 29634, USA. Tel: 1-864-656-1138. E-mail: pdawson@ clemson.edu
}

\author{
Received: May 1, $2017 \quad$ Accepted: June 9, $2017 \quad$ Online Published: June 28, 2017 \\ doi:10.5539/jfr.v6n4p111 URL: https://doi.org/10.5539/jfr.v6n4p111
}

\begin{abstract}
The objective of this study was to determine the transfer and survival of bacteria during the handling and storage of lemons and transfer of bacteria during handling of ice. Ice and lemon slices are handled and stored in public eating places and used in beverages. During handling and storage the contamination and growth of bacteria may occur leading to the spread of disease. To fulfill the objective, hands were inoculated with Escherichia coli prior to handling of wet and dry whole lemons and in a separate experiment, ice cubes were handled. E. coli transferred to whole lemons or ice after handling were determined. The CFU per lemon and percentage of $E$. coli transferred were greater for wet lemons $-6123 \mathrm{cfu}$ and $4.62 \%$ compared to $469 \mathrm{cfu}$ and $.2 \%$ for dry lemons. The second experiment found from 2 to $67 \%$ of the bacteria on hands were transferred to ice by hands and from 30 to $83 \%$ of the bacteria on scoops were transferred to ice. In a third experiment, lemons were inoculated with $E$. coli, then sliced and stored at 4 or $22 \mathrm{C}$ and tested at 0,4 and $24 \mathrm{hr}$. Lemons stored at room temperature $\left(22^{\circ} \mathrm{C}\right) \mathrm{had}$ an increase in $E$. coli population after 24 hour while those stored under refrigeration had a decrease even though bacteria did survive on lemons in either case.
\end{abstract}

Keywords: lemons, lemon slices, ice, E. coli, handling, storage

\section{Introduction}

The non-alcoholic beverage market is an $\$ 841$ billion industry (Bailey, 2014) with the annual alcoholic beverage market at $\$ 494$ billion (beer), \$319 billion (wine) and \$637 billion (spirits) (Marketrealist, 2014). Beverages are often prepared with the addition of ice and cut fruit slices such as lemons, limes and oranges. These drink items are also often handled by a server or the individual consuming the drink which offers an opportunity for contamination which is a possible source of contamination leading to foodborne illness.

\subsection{Foodborne Illness}

Thirty-one major pathogens cause 9.4 million cases of foodborne illness and about 2,612 deaths from tainted food annually (CDC, 2011). The Economic Research Service reports that foodborne illness costs $\$ 6.9$ billion in medical expenses, lost productivity and deaths (USDA, 2014). Hand cleanliness or lack thereof, plays a major role in transmission of infectious disease in various public sectors including the food industry (Jumma, 2005).

\subsection{Ice}

The US Food and Drug Administration defines ice as food (FDA, 2010) and the World Health Organization has stated that ice coming in contact with food should have the same level of safety and quality as drinking water (WHO, 1997). Ice used for human consumption can be contaminated with pathogenic organisms and be a vector for spreading foodborne illness (Falcao, Dias, Correa \& Falcao, 2002; Gerokomou et al., 2011). In 1987, the Centers for Disease Control reported a 4-state outbreak of Norwalk virus in Pennsylvania, Delaware and New Jersey from contaminated ice estimated to have affected more than 5,000 people (Levine, Stephenson \& Craun, 1990). Contaminated ice was also a prominent transmission vector for spreading the 1991 cholera epidemic in Peru causing 7922 illnesses, 17 deaths and also expanding throughout Latin America (Ries et al., 1992). More recently, 
diarrheagenic E. coli has been found in commercial ice produced in Brazil (Falcao, Falcao \& Gomez, 2004). In the past, pathogens have been detected in ice from ice making machines (Stout, Yu \& Muraca, 1985; Panwalker \& Fuhse, 1986; Laussucq, Baltch, Smith, Smithwick, Davis et al., 1988; Wilson, Hogg \& Barr, 1997). In a survey of over 3,500 samples of ice used to cool drinks, Nichols, Gillespie \& Louvois, (2000) found that 9\% contained coliforms at greater than $100 \mathrm{cfu} / 100 \mathrm{ml}$ and $11 \%$ had total aerobes at greater than $1000 \mathrm{cfu} / \mathrm{ml}$. Ice produced at retail outlets in Nigeria were contaminated with more than $1000 \mathrm{cfu} / \mathrm{ml}$ and isolates displayed 100, 67 and $87 \%$ resistance to Ampicillin, Erythromycin and Tetracycline, respectively (Lateef, Oloke, Guegium-Kana \& Pacheco, 2006).

\subsection{Lemons}

Food establishments often place lemons in open containers at room temperature throughout the day for consumer access allowing consumers and food service workers to handle lemons for cutting and when serving slices with beverages. Lemons naturally contain bacteria that provide a symbiotic relationship with the fruit (Gardner, Feldman, \& Zablotowicz, 1982). Similarly, human hands naturally contain bacteria such as Micrococcus luteus and Serratia. rubidea that transfer from humans to other objects. Transfer is particularly high when fingers contact lips (Rusin, Maxwell, \& Gerba, 2002). Martinez-Gonzalez et al. (2003) found that orange surfaces inoculated with 2.3, 3.6 and $4.4 \log _{10} \mathrm{CFU} / \mathrm{cm}^{2}$ Salmonella Typhimurium, E. coli and Listeria monocytogenes, respectively resulted in 1.0, 2.3 and $2.7 \log _{10} \mathrm{CFU} / \mathrm{ml}$ for these organisms in orange juice prepared from the inoculated oranges. Cut lemons are located at self-service drink stations for consumers to handle which increases the number of people touching lemon slices, many who are not food service workers and not subject to hand washing regulations. Lemons are held without refrigeration and to reduce waste, leftover lemons are sometime placed under refrigeration overnight for use the next day. Thus lemon slices are exposed to numerous opportunities for contamination and held unrefrigerated to allow microbial growth prior to use by consumers.

\subsection{Hand Sanitation and Cross Contamination}

Cross contamination in food service may play an important role in foodborne illness (Fendler, Dolan \& Williams, 1998). During food preparation, bacteria on hands can be transferred to raw foods from hands and indirectly from other surfaces (Montville, Chen \& Schaffner, 2002). Hands can also be a source for contamination from food workers that may be ill by not have overt symptoms who shed pathogens (Rocourt \& Cossart, 1997; Rose \& Slifko, 1999). Numerous studies have examined the transfer of bacteria to food from food contact surfaces including stainless steel (Kusumaningrum, Riboldi, Hazelberger \& Beumer, 2003; Moore, Sheldon \& Jaykus, 2003; Rodriguez \& McLandsborough, 2007; Kesiken, Todd \& Ryser, 2008), fabrics (Marples \& Towers, 1979; Sattar et al. , 2001; Scott \& Bloomfield, 1990), gloves (Legg, Khela, Madie, Fenwick, Quynh \& Hedderley, 1999; Heal et al., 2003; Montville et al., 2001; Blom, Gozzard, Heal, Bowker, \& Estela, 2002; Gill \& Jones, 2002; Mackintosh \& Hoffman, 1984; Patrick, Findon, \& Miller, 1997; Scott \& Bloomfield, 1990; Shale, Jacoby \& Plaatjies, 2006) and hands (Scott \& Bloomfield, 1990; Legg et al., 1999; Merry, Miller, Findon, Webster \& Neff, 2001). A scoop, hands or other utensil is often used to deliver ice to a beverage offering the opportunity for cross contamination. The objectives of this study were to determine 1) to what extent bacteria is transferred to lemons when handled with contaminated hands; 2) the degree of bacterial transfer to ice when handled with contaminated hands or scoops; and 3) if bacterial numbers will increase during the storage of contaminated lemons.

\section{Methods}

\subsection{Bacterial Inoculum}

An Escherichia coli ampicillin-resistant strain with a fluorescent gene was used for the bacterial transfer and survival studies. A non-pathogenic E. coli strain JM109 was labeled with jellyfish green fluorescent protein according to the following protocol as described previously (Jiang et al., 2002). The competent bacterial cells were electroporated in a Gene Pulser II (Bio-Rad) with plasmid vector pGFPuv (ClonTech, Palo Alto, CA). Transformants were selected from isolated colonies grown on Luria-Bertani agar (LB) plates containing $100 \mathrm{~g}$ ampicillin/mL. The resulting ampicillin-resistant transformants emitted bright green fluorescence under UV light. The stability of GFP label in the E. coli strain was determined by streaking on trypticase soy agar (TSA) plates containing $100 \mathrm{~g}$ ampicillin/mL for several generations. The E. coli JM 109 culture was held in a $-80^{\circ} \mathrm{C}$ freezer in vials containing tryptic soy broth (TSB) (Becto ${ }^{\mathrm{TM}}$, Becton Dickinson and Company Sparks, MD, USA) supplemented with $20 \%(\mathrm{v} / \mathrm{v})$ glycerol (Sigma, St. Louis, MO, USA). The frozen vial was thawed at room temperature prior to culturing. From this thawed vial, $0.1 \mathrm{~mL}$ of culture was transferred to $10 \mathrm{~mL}$ TSB containing $0.5 \%$ ampicillin (Sigma, St. Louis, MO, USA) in 2 loosely screw-capped tubes and then the tubes were incubated for $16-18 \mathrm{~h}$ at $37^{\circ} \mathrm{C}$ with vigorous shaking (Thermolyne Maxi-Mix III type 65,800, 
Barnstead/Thermolyne, Dubuque, IA). The second transfer was prepared from this first transfer culture by adding $0.1 \mathrm{~mL}$ from the first transfer tube to another fresh $10 \mathrm{~mL}$ TSB (DIFCO) with $0.5 \%$ ampicillin (Sigma), and again incubated for $16-18 \mathrm{~h}$ at $37^{\circ} \mathrm{C}$ with shaking. After incubation, the cells were harvested by centrifugation at $3000 \mathrm{rpm}(1200 \mathrm{~g})$ (IEC HN-SII Centrifuge, International Equipment CO., Inc., Needham Heights, MA, USA), then the pellet re-suspended in $10 \mathrm{~mL}$ of sterile peptone solution (0.1\%) (Bacto peptone, Becton Dickinson) to obtain a population of approximately 6-7 $\log \mathrm{CFU} / \mathrm{mL}$. Initial cell populations were verified by enumeration of the cells following surface plating in TSA containing $0.5 \%$ ampicillin (DIFCO ${ }^{\mathrm{TM}}$, Becton Dickinson and company Sparks, MD, USA) and incubation at $37^{\circ} \mathrm{C}$ for $24 \mathrm{~h}$.

\subsection{Experiment 1: E. Coli Transfer from Hands to Whole Lemons}

\subsubsection{E. Coli on Hands}

Each subject washed their hands with warm water and soap, allowed their hands to air dry, and then $1 \mathrm{~mL}$ of the $E$. coli inoculum was deposited in the center of their dominate hand. The E. coli was applied by rubbing hands together for $30 \mathrm{sec}$, and then hands were allowed to air dry for $30 \mathrm{sec}$. To enumerate bacteria on subject's hands, both hands (separately) were placed into a sterile stomacher bag with $20 \mathrm{~mL}$ of sterile $0.1 \%$ peptone and rinsed for 30 seconds, covering all fingers, palm, and back of the hand. Next, $1 \mathrm{~mL}$ of the peptone solution was removed from the stomacher bag, placed into $9 \mathrm{~mL}$ of sterile $0.1 \%$ peptone and serially diluted. A $0.1 \mathrm{ml}$ aliquot from sample dilutions were pipetted and spread onto TSA plates containing $100 \mathrm{~g}$ ampicillin $/ \mathrm{mL}$. Plates were held for 5-10 minutes and were then inverted and placed in an incubator at $37^{\circ} \mathrm{C}$ for 24 hours. The next day the plates were inspected under UV light and plates with 25 to $250 \mathrm{CFU} /$ plate were counted and then multiplied by the dilution number then converted to CFU/hand and $\log \mathrm{CFU} / \mathrm{hand}$ based on serial dilutions.

\subsubsection{E. Coli Transferred to Lemons}

Four treatments were employed to determine bacterial transfer from hands: 1 . Un-inoculated hands handling dry lemons, 2. inoculated hands handling dry lemons, 3. Un-inoculated hands handling wetted lemons, and 4. Inoculated hands handling wetted lemons. Each subject washed their hands then handled a lemon for 30 seconds by rolling the lemon between hands.

For the inoculated treatments ( 2 and 4 ) the procedure was repeated as described for un-inoculated hands only instead, hands were inoculated as described for section 2.2.1, then lemons were handled for 30 seconds. Lemons handled by inoculated or un-inoculated hands were placed into separate filter stomacher bags, each with $20 \mathrm{~mL}$ of sterile $0.1 \%$ peptone solution. The lemon and peptone were mixed for $30 \mathrm{sec}$ in the bag. Then $1 \mathrm{~mL}$ samples of the liquid from the bags were taken in duplicate, serially diluted as previously described then plated on TSA. Samples were incubated and counted as described for the hand sample.

Serial dilutions were then prepared, plated, and spread in duplicate and plates were incubated and counted as previously described. Bacteria were counted 24 hours after plating by identifying colonies under a UV light then converted to CFU/lemon and $\log \mathrm{CFU} / \mathrm{lemon}$ as described for hands (2.3.1).

The $\%$ transfer of $E$. coli from hands to lemons was calculated using (1):

$$
\% \text { transfer }=\frac{C F U \text { recovered from lemons }}{C F U \text { recovered from hands }+C F U \text { recovered from lem }} \quad \times 100
$$

\subsection{Experiment 2: Transfer of E. Coli to Ice from Hands and Metal Scoops}

The bacterial inoculum was prepared for the ice transfer experiments in the same manner as described under 2.1 for lemons.

\subsubsection{Inoculation of E. Coli on Hands and Scoops}

Each subject will wash their hands with warm water and soap, allow their hands to air dry, and then $1 \mathrm{~mL}$ of the E. coli inoculum will be deposited in the center of their dominate hand. The E. coli will be applied by rubbing hands together for $30 \mathrm{sec}$, and then hands will be allowed to air dry for $30 \mathrm{sec}$. For scoops, a sanitized scoop was inoculated by placing $1 \mathrm{~mL}$ of $E$. coli inoculum in the center of the scoop then spread across the scoop surface using a sterile glass rod then allowed to dry for 30 seconds.

\subsubsection{E. Coli Transferred To Ice from Scoops and Hands}

Four treatments were employed to determine bacterial transfer from hands to ice: 1. Un-inoculated hands handling ice, 2. inoculated hands handling ice, 3. Un-inoculated scoop handling ice, and 4. Inoculated scoops 
handling ice. Each subject washed their hands then picked up a handful of ice, the immediately placed the ice in a filter stomacher bag containing $20 \mathrm{~mL}$ of sterile $0.1 \%$ peptone solution. This procedure was repeated with inoculated hands and both inoculated and un-inoculated scoops. The ice and peptone water were mixed for 30 sec in the bag. To enumerate bacteria on subject's hand the dominant hand used to pick up ice were placed into a sterile stomacher bag with $20 \mathrm{~mL}$ of sterile $0.1 \%$ peptone and rinsed for 30 seconds, covering all fingers, palm, and back of the hand. For inoculated scoops, 5 pieces of ice were placed into the scoop and gently moved back and forth for 5 seconds then the ice was immediately placed into a filter stomacher bag containing $20 \mathrm{ml}$ of sterile $0.1 \%$ peptone solution.

Next, $1 \mathrm{~mL}$ of the peptone solution was removed from each stomacher bag, placed into $9 \mathrm{~mL}$ of sterile

$0.1 \%$ peptone and serially diluted. Nine $\mathrm{ml}$ test tubes of sterile peptone solution $(0.1 \%)$ were used for serial dilution of samples. $0.1 \mathrm{ml}$ from sample dilutions were pipetted and spread onto TSA plates containing $100 \mathrm{~g}$ ampicillin $/ \mathrm{mL}$. Plates were held for 5-10 minutes and will be then inverted and placed in an incubator at $37^{\circ} \mathrm{C}$ for 24 hours. The next day the plates were inspected under UV light and appropriate petri dishes will be chosen for counting. Plates with a number of colonies ranging from 25 to $250 \mathrm{CFU} /$ plate were counted and converted to $\mathrm{CFU} / \mathrm{ml}$ based on the dilution. Plates were examined under the UV light and only the fluorescent bacteria counted. Bacterial counts were converted to CFU/hand or scoop and log CFU/hand or scoop based on the amount of rinse solution used. Percentage of $E$. coli transferred from hands to ice will be calculated using (1):

$$
\% \text { transfer } \frac{C F U \text { recovered from ice }}{C F U \text { recovered from hands (scoops) }+C F U \text { recovered fro }} \quad \mathrm{X} \quad=
$$

Another experiment (2-1) was conducted to determine the transfer of E. coli from metal scoops to ice at 4 different times after inoculation $(0,1 \mathrm{hr}, 1.5 \mathrm{hr}$ and $2 \mathrm{hr})$ and for three sequential times using the same scoop. Scoops were inoculated with the E. coli ampicillin-resistant strain with a fluorescent gene as described in section 2.3.1. prior to exposure to ice. Bacteria were enumerated using the method that was previously described in section 2.2.2. at each of the storage times and for each of the sequential exposure to ice.

\subsection{Experiment 3: Survival of E. Coli on Sliced Lemons}

Survival of E. coli on lemon slices was tested at three different time intervals $(0,4$, and $24 \mathrm{hr})$ and at refrigerated $\left(4 \pm 2^{\circ} \mathrm{C}\right)$ and room $\left(21 \pm 2^{\circ} \mathrm{C}\right)$ temperatures. Lemons were inoculated with the E. coli ampicillin-resistant strain with a fluorescent gene as described in section 2.1 by placing each lemon in sterile bag containing $20 \mathrm{ml}$ of a $~ 6$ $\log \mathrm{CFU} / \mathrm{mL}$ of E. coli solution which was shaken for $30 \mathrm{sec}$ then the lemon removed and allowed to dry for 5 min. Lemons were then sliced into quarters. One set of slices were enumerated for E. coli after 10 min while other lemons were stored for 4 and $24 \mathrm{hr}$ at room or refrigerated temperature. Bacteria were enumerated using the method that was previously described in section 2.2.1. at each of the storage times.

\subsection{Statistical Analysis}

All three experiments were conducted as completely randomized designs and simple mean, standard deviation, minimum and maximum values were determined for treatment using the Statistical Analysis System (SAS, 2014). Experiment 1 (bacterial transfer from hands to lemons) had 11-13 subjected per each of 3 replications with each observation duplicated for a total of 70 observations per treatment (wet or dry lemons). Experiment 2 (bacterial transfer from hands or scoops to ice) had 11 subjects per each of 3 replications with each observations duplicated for a total of 66 observations per treatment (hand or scoop). In a separate experiment 2.1 (bacterial transfer from 3 sequential scoops held for up to 2 hours) was conducted using three replications having 2 variables of (1) 1-3 scoops in sequence and (2) holding time (0,1,1.5 and 3 hours). Two scoops were utilized for each of 3 replications and each scoop was analyzed in duplicate yielding 12 observations per treatment. Experiment 3 (bacterial survival on stored lemons) had 2 variables of (1) storage temperature (room or refrigerated) and (2) storage time ( 0,4 and 24 hours) with duplicates for each of 5 replications for a total of 10 observations for each combined storage temperature and storage time treatment combination. Treatments were subjected to an analysis of variance, and since the treatments had a significant effect $(\mathrm{p}>0.05)$, were separated using the pdiff command of SAS (2014).

\section{Results and Discussion}

\subsection{Experiment 1: E. Coli Transfer from Hands to Whole Lemons}

No fluorescent $E$. coli were recovered from lemons handled with un-inoculated hands. One interesting finding was that all $(100 \%)$ of the lemons that were wet prior to handling with inoculated hands showed bacterial 
transfer while only $30.3 \%$ of lemons that were dry prior to handling with inoculated hands had bacteria detected after handling. The average CFU per lemon when wet was 6123 with an average transfer of $4.82 \%$ (Table 1). Conversely, the dry lemons had an average CFU of 469 (Table 1) and a transfer of $0.2 \%$.

Table 1. Mean, median, range of the population and $\%$ transfer of bacteria on lemons from hands inoculated with E. coli

\begin{tabular}{lllllll}
\hline & CFU/lemon & \multicolumn{2}{c}{ LogCFU/lemon } & \multicolumn{2}{l}{ \%CFU transferred } \\
\hline & Dry lemons & Wet lemons & Dry lemons & Wet lemons & Dry lemons & Wet lemons \\
\hline Mean & $469^{\mathrm{b}}(1502)$ & $6912^{\mathrm{a}}$ & $2.67^{\mathrm{b}}(3.2)$ & $3.84^{\mathrm{a}}$ & $0.20^{\mathrm{b}}(0.65)$ & $4.86^{\mathrm{a}}$ \\
Stand Error & 223 & 1644 & 0.16 & 0.09 & 0.07 & 0.8 \\
Median & 0 & 2180 & 0 & 3.34 & 0 & 2.48 \\
Maximum & 11720 & 62400 & 4.07 & 4.8 & 2.57 & 29.52 \\
Minimum & 0 & 40 & 0 & 1.60 & 0 & 0.02 \\
\hline
\end{tabular}

${ }^{a, b}$ means with different superscripts are significantly different $(p \leq 0.05) . n=70$

(values in parenthesis are calculated from only the $30 \%$ having transfer)

Patrick, Findon \& Miller (1997) also found the wetness of hands (degree of drying) was directly related to the percentage of bacteria transferred to food. In the current study, the transfer of bacteria was greater when lemons were wet. Perez-Rodriquez et al. (2008) summarized the modelling of bacterial transfer between recipient and donor surfaces including intrinsic factors of bacterial hydrophilicity/hydrophobicity and biofilm development, and environmental factors including contact time, pressure, surface roughness and surface moisture. Based previously reviewed research, Perez-Rodriquez et al. (2008) concluded that increased moisture increased bacterial transfer from surfaces to food. Kusumaningrum et al. (2003) found a greater transfer of bacteria to cucumber slices than roasted chicken from inoculated stainless steel indirectly supporting the finding that moisture facilitates bacterial transfer. Shale, Jacoby \& Plaatjies (2006) reported that transfer of Staphylococcus spp. was greater between meat and surfaces than between airborne bacteria in meat abattoirs. Furthermore, there was no difference in the degree which bacteria adhered to hands or gloves according to Legg et al. (1999).

Moore et al. (2003) found varying results for transfer from inoculated stainless steel to wet or dry lettuce. For example, transfer of Salmonella Typhimurium from stainless steel to dry lettuce ranged from 6 to $66 \%$ (depending on how long the bacteria were on the surface before lettuce contact) and from 23 to $31 \%$ for wet lettuce. Also for Campylobacter jejuni transfer for was from 16 to $38 \%$ for dry lettuce and from 15 to $27 \%$ for wet lettuce. Gill \& Jones (2002) reported greater transfer of $E$. coli from meat to gloves and from gloves to meat when gloves were wet with between 2 to $4 \log$ cfu/piece of meat transferred from hands and gloves contaminated by handling inoculated meat.

\subsection{Experiment 2. Transfer of E. Coli to Ice from Hands and Metal Scoops}

Ice is a known transmission vector of pathogenic microorganisms in human foodborne illness (Levine, Stephenson \& Craun, 1990; Reis et al., 1992; Falcao et al. 2004). In these studies the pathogen was carried in water used to create the ice however, cross contamination due to handling food and ice is also a cause of foodborne illness (Fendler, Dolan \& Williams, 1998; Montville, Chen \& Schaffner, 2002). Bacteria can reside on hands (Rocourt \& Cossart, 1997; Rose \& Slifko, 1999) and stainless steel food contact surfaces (Kusumaningrum, Riboldi, Hazelberger \& Beumer, 2003; Moore, Sheldon \& Jaykus, 2003; Rodriguez \& McLandsborough, 2007; Kesiken, Todd \& Ryser, 2008) and transfer bacteria to food. In the current study an average of $19.5 \%$ of the bacteria on hands were transferred to ice and $66.2 \%$ of bacteria on scoops were transferred to ice (Table 2). The higher level of transfer from scoops compared to hands is expected due to the lack of attachment on stainless steel compared to skin.

Table 2. Mean, median, range of the population and $\%$ transfer of bacteria on ice from hands and scoops inoculated with $E$. coli

\begin{tabular}{lllllll}
\hline & \multicolumn{2}{l}{ CFU/hand or scoop } & \multicolumn{2}{l}{ LogCFU/hand or scoop } & \multicolumn{2}{l}{ \%CFU transferred } \\
\hline & Hand Ice & Scoop Ice & Hand Ice & Scoop Ice & Hand Ice & Scoop Ice \\
\hline Mean & $23676^{\mathrm{b}}$ & $506800^{\mathrm{a}}$ & $4.1^{\mathrm{b}}$ & $5.6^{\mathrm{a}}$ & $19.5^{\mathrm{b}}$ & $66.2^{\mathrm{a}}$ \\
Stand Error & 3284 & 60773 & 0.07 & 0.04 & 1.9 & $1.2^{2}$ \\
Median & 16698 & 369380 & 4.2 & 5.6 & 13.9 & 67.8 \\
Maximum & 1102465 & 1900030 & 5.0 & 6.3 & 67.0 & 82.5 \\
Minimum & 607 & 93610 & 2.8 & 0.3 & 1.9 & 30.0 \\
\hline
\end{tabular}

a,b means with different superscripts are significantly different $(\mathrm{p} \leq 0.05) . \mathrm{n}=66$. 
Transfer of bacteria from contaminated ice holding bins or scoops to ice may be an issue since Hampikyan, Bigol, Cetin \& Colak (2017) reported finding E. coli in $6.7 \%$ of ice samples, $22 \%$ of ice chest samples but no positive $E$. coli from water samples used to make the ice.

In a separate experiment, the time after inoculation and sequential scoops were evaluated as factors affecting $E$. coli transfer to ice. A significant effect $(\mathrm{p} \leq 0.05)$ of holding scoops after inoculation and for taking multiple ice samples in sequence using the same scoop was found on the population of E. coli transferred to ice (Figure 1). Less bacteria was transferred in the second scoopful of ice at 0 and 1 hour after inoculation but relatively high levels of bacteria were still transferred from the scoop to the ice in the third scoopful. The percentage of bacteria transferred at 0 hours for scoop sample 1,2, and 3 was 71,53 and $49 \%$ respectively. This trend held for all of the holding times with a decreasing number of bacteria as holding time increased. The overall difference in $\%$ transfer between the 3 scoopfuls taken in sequence was $11 \%$ between scoopful 1 and 2 and $16 \%$ between scoopful 1 and 3. Overall the percentage of bacteria transferred to ice was significantly different between scoopfuls 1 and 2 and between 1 and 3 but not 2 and $3(\mathrm{p} \leq 0.05)$. . This repeated transfer of $E$. coli from scoops to ice is supported by previous research that reported bacteria residing on surfaces could shed during repeated contact with other surfaces (Moore et al., 2003).

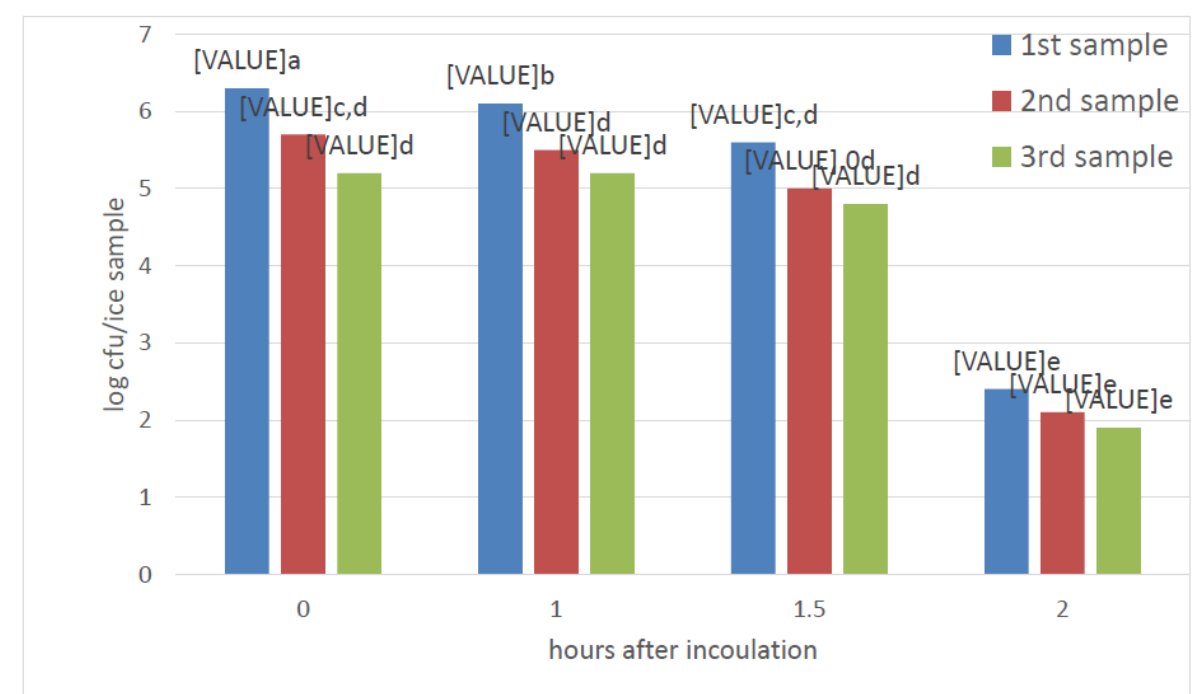

Figure 1. The population of E. coli recovered from ice exposed to scoops for 5 seconds then held for different times after inoculation and then exposed three sequential times using the same scoop

${ }^{a-e}$ means with different superscripts are significantly different $(\mathrm{p} \leq 0.05)$. $\mathrm{n}=12$. Standard error for the 12 treatments ranged from 0.16 to 0.35 logcfu/ice sample.

\subsection{Experiment 3. Bacterial Survival during Holding of Lemons}

During the storage of lemons, bacterial population was highest for refrigerated lemons at time $\mathrm{t}=0$. Lemons held at room temperature lemons had the highest E. coli populations at 0 and 24 hours (Figure 2). Refrigeration reduced E. coli populations from about $5 \operatorname{logs}$ cfu/lemon to about $2 \operatorname{logs}$ after 4 hours which did not further diminish after 24 hours of refrigerated storage. Beumer \& Kusamaningrum (2003) found that leftover foods stored at $10^{\circ} \mathrm{C}$ increased by 2-3 log cycles in 3 days. Overall, to prevent growth and transfer, lemons should be handled dry and kept refrigerated. Enteropathogenic bacteria (Shigella and Salmonella spp.) increased in population several $\log$ cycles in 6 hours on cut papaya and watermelon when stored at $25-27^{\circ} \mathrm{C}$ and the application of lemon juice to the fruit surface reduced the population of $S$. typhii but the bacteria began to increase in population after 2 hours (Escartin, Ayala \& Lozano, 1989). Cross contamination in food service environments is a major factor in many foodborne illness outbreaks (Bloomfield \& Scott, 1997; Guzewich \& Ross, 1999). 


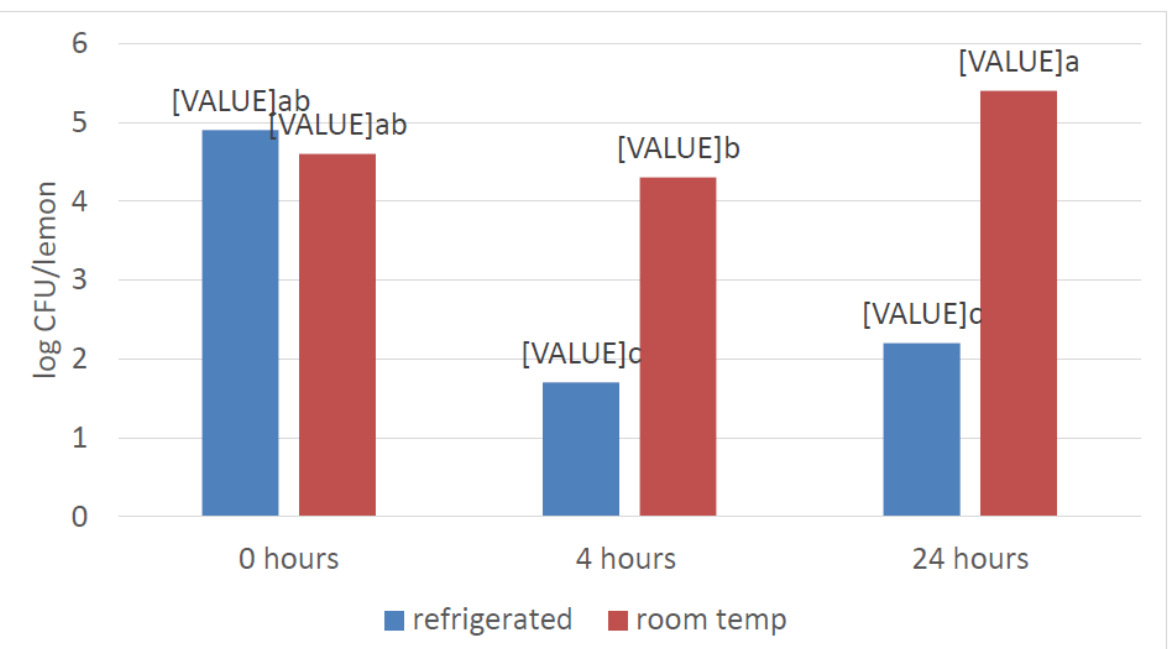

Figure 2. Population of E. coli on lemons after different storage times held at room temperature or under refrigeration

${ }^{a, b}$ means with different superscripts are significantly different $(\mathrm{p} \leq 0.05)$. $\mathrm{n}=10$. Standard deviation for the 6 treatments ranged from 0.26 to 1.9 .

Chen, Jackson, Chai \& Schaffner (2001) modeled the transfer of a surrogate bacterium Enterobacter aerogenes, starting from raw chicken to hands, then after washing of hands, the transfer of bacteria remaining of hands to lettuce. These researchers found transfer rates as high as $100 \%$ with over $3 \operatorname{logs}$ recovered on lettuce from an initial inoculation of 8 logs on chicken despite the two transfer steps and hand washing before touching lettuce. Chen et al (2001) also demonstrated touching other surfaces such as spigots to turn on water would create surfaces that could, in turn be sources of contamination.

\subsection{Bacteria in Beverages}

Harmful bacteria can be added to beverages by handling of ice and other garnishes. In fact Loving \& Perz (2007) found $69.3 \%$ of lemon slices put in drinks in 21 different restaurants were carrying bacteria or fungi many of which are associated with human contamination. A common fallacy is that acidic and alcoholic beverages will protect the consumer from harmful microorganisms. In fact, Dickens, DuPont \& Johnson (1985) found that 4 pathogens frozen in ice and allowed to melt for 30 minutes in cola, soda, Scotch ( 80 proof), a mixture of Scotch/soda and Tequila (86 proof) were not eliminated. The following percentages were recovered in each of the following; $100 \%$ in club soda, 55-74\% in cola, 64-94\% in scotch and soda, 11-16\% in pure Scotch and 5-10\% in pure Tequila. Two other studies found a slight inhibitory effect of drink acidity but only when the bacteria were exposed to acidic drinks for a day or more. In a study to determine the best beverage to consume to avoid "traveler's diarrhea" or "Montezuma's revenge." Sheth, Wisniewski \& Franson (1988) reported that wine, diet cola and sour mix eliminated Salmonella and E. coli after 48 hours of exposure while beer and regular cola had a strong inhibitory effect but did not eliminate these bacteria. A second study examined orange drinks with $\mathrm{pH}$ levels of 3.0, 4.9 and 6.8 finding that only the $3.0 \mathrm{pH}$ drink reduced E. coli and Salmonella spp. populations but only to low levels after 30 hours of exposure (Massa, Facciolongo, Rabasco \& Caruso, 1998). In these studies, extremely long exposure times were used, a scenario not likely to occur with drinks served with ice or fresh cut lemons. Thus the contamination of ice or cut fruit such as lemons to drinks could be a potential vehicle to transmit bacteria. Food service workers are the primary of contamination of food with norovirus, hepatitis A and Shigella spp. and can transfer other pathogens such as E. coli and Salmonella spp. to food (Lynch, Tauxe \& Hedberg, 2009) thus sanitation of surfaces contacting ice and lemons served in beverages should be considered in minimizing food contamination.

\section{References}

Bailey, S. (2014) A guide to the non-alcoholic beverage industry. Market Realist. November 20, 2014 http://marketrealist.com/2014/11/guide-non-alcoholic-beverage-industry/ accessed 4-18-2017.

Beumer, R. R., \& Kusumaningrum, H. (2003). Kitchen hygiene in daily life. International Biodeterioration \& Biodegradation, 51(4), 299-302. https://doi.org/10.1016/S0964-8305(03)00041-6 
Blom, A. W., Gozzard, C., Heal, J., Bowker, \& Estela, C. M. (2002). Bacterial strike-through of re-usable surgical drapes: the effect of different wetting agents. Journal of Hospital Infection, 52(1), 52-55. https://doi.org/10.1053/jhin.2002.1262

Bloomfield, S. F., \&Scott, E. (1997). Cross-contamination and infection in the domestic environment and the role of chemical disinfectants. Journal of Applied Microbiology, 83, 1-9.

https://doi.org/10.1046/j.1365-2672.1997.00199.x

CDC (2011). http://www.cdc.gov/foodborneburden/ accessed 2/28/2017.

Chen, Y., Jackson, K. M, Chea, F. P., \& Schaffner, D. W. (2001). Quantification and variability analysis of bacterial cross-contamination rates in common food service tasks. Journal of Food Protection, 64(1), 72-80. https://doi.org/10.4315/0362-028X-64.1.72

Falcao, J. P., Dias, A. M. G., Correa, E. F., \& Falcao, D. P. Microbiological quality of ice used to refrigerate foods. Food Microbiology, 19, 269-276. http://dx.doi.10.1006/yfmic.490

Dickens, D. L., DuPont, H. L., \& Johnson, P. C. (1985). Survival o bacterial enteropathogens in the ice of popular drinks. Journal of the American Medical Association, 253(21), 3141-3143. https://doi.org/10.1001/jama.1985.03350450113034

Escartin, E. F., Ayala, A. C., \& Lozano, J. S. (1989). Survival and growth of Salmonella and Shigella on sliced fresh fruit. Journal of Food Protection, 52(7), 471-472. https://doi.org/10.4315/0362-028X-52.7.471

FDA, (2010). US Food and Drug Association, FDA regulates the safety of packaged ice. International Packaged Ice 390 Association. Available at: http://www.packagedice.com/downloads/FDA\%20Regulates\%20the\%20Safety\%20of\%20Pa392 ckaged\%20Ice.pdf. accessed on 4-23-2017.

Falcao, J., A. Dias, E. Correa, \& Falcao, D. (2002). Microbiological quality of ice used to refrigerate foods. Food Microbiology, 19, 269-276 https://doi.org/10.1006/fmic.2002.0490

Falcao, J. P., Falcao, D. P., \& Gomez, T. A. T. (2004). Ice as a vehicle for diarrheagenic Escherichia coli. $\begin{array}{llll}\text { International Journal of Food } & \text { Microbiology, }\end{array}$ https://doi.org/10.1016/S0168-1605(03)00327-1

Fendler, E. J., Dolan, M. J., \& Williams, R. A. (1998). Hand washing and gloving for food protection. Part I. Examination of the evidence. Dairy and Food Environmental Sanitation, 18, 814-823.

Gardner, J. M., Feldman, A. W., \& Zablotowicz, R. M. (1982). Identity and Behavior of Xylem-Residing Bacteria in Rough Lemon Roots of Florida Citrus Trees. Applied and Environmental Microbiology, 43(6), $1335-1342$.

Gerokomou, V., Voidarou, C. Vatopoulos, A., Velonakis, E., Rozos, G., Alexopoulos, A., Plessas, S., Stavropoulou, E., Bezirtzoglou, E., Demertzis, P. G., \& Akrida-Demertizi, K. (2011). Physical, chemical and microbiological quality of ice used to cool drinks and foods in Greece and its public health implications Anaerobe, 17(6), 351-353. https://doi.org/10.1016/j.anaerobe.2011.06.005

Gill, C. O., \& Jones, T. (2002). Effects of wearing knitted or rubber gloves on the transfer of Escherichia coli between hands and meat. Journal of Food Protection, 65(6), 1045-1048. https://doi.org/10.4315/0362-028X-65.6.1045

Guzewich, J. J., \& Ross, M. P. (1999). Evaluation of risks related to microbiological contamination of ready-to-eat food by food preparation workers and the effectiveness of interventions to minimize those risks. http://vm.cfsan.fda.gov/;ear/rterisk.html.

Hampikyan, H., Bingol, E. B., Cetin, O., \& Colak, H. (2017). Microbiological quality of ice and ice machines in food establishments. Journal of Water and Health, 15(2), available online; https://doi.org/10.2166/wh.2017.159

Heal, J. S., Blom, A. W., Titcomb, D., Taylor, A., Bowker, K., \& Hardy, J. R. W. (2003). Bacterial contamination of surgical gloves by water droplets spilt after scrubbing. Journal of Hospital Infection, 53(2), 136-139. https://doi.org/10.1053/jhin.2002.1352

Jumma, P. A. (2005). Han hygiene. Simple and complex. International Journal of Infectious Diseases, 9, 3-14. https://doi.org/10.1016/j.jijid.2004.05.005

Keskinen, L. A., Todd, E. D. \& Ryser, E. T. (2008). Transfer of surface-dried Listeria monocytogenes from 
stainless steel knife blades to roast turkey breast. Journal of Food Protection, 71(1), 176-181. https://doi.org/10.4315/0362-028X-71.1.176

Kusumaningrum, H. D., Riboldi, G., Hazelberger, W. C., \& Beumer, R. R. (2003). Survival of foodborne pathogens on stainless steel surfaces and cross-contamination to foods. International Journal of Food Microbiology, 85, 227-236. https://doi.org/10.1016/S0168-1605(02)00540-8

Lassucq, S., Baltch, A. L., Smith, R. P., Smithwick, R. W., Davis, B. J., Desjardin, E. K., Silcox, A., Spellacy, A. B., Zeimes, R. T., Gruft, H. M., Good, R. C., \& Cohen, M. L. (1988). Nosocomial Mycobacterium foruitum colonization from a contaminated ice machine, American Review of Respiratory Disease, 138(4), 891-894. https://doi.org/10.1164/ajrccm/138.4.891

Lateef, A., Oloke, J. K., Gueguim Kana, E. B., \& Pacheco, E. (2006). The microbiological quality of ice used to cool drinks and foods in Ogbomoso Metropolis, Southwest, Nigeria. Internet Journal of Food Safety, 8, $39-43$.

Legg, S. J., Khela, N., Madie, P., Fenwick, S. G., Quynh, V., \& Hedderly, D. I. (1999). A comparison of bacterial adherence to bare hands and gloves following simulated contamination from a beef carcass. International Journal of Food Microbiology, 53(1), 69-74. https://doi.org/10.1016/S0168-1605(99)00153-1

Levine, W. C., Stephenson, W. T., \& Craun, G. F. (1990). Waterborne Disease Outbreaks, 1986-1988. https://www.cdc.gov/mmwr/preview/mmwrhtml/00001596.htm accessed 4-23-2017.

Loving, A.L. \& Perz, J. 2007. Microbial flora on restaurant beverage lemon slices. Journal of Environmental Health 70(5): 18-22.

Lynch, M. F., Tauxe, R. V., \& Hedberg, C. W. (2009). The growing burden of foodborne outbreaks due to contaminated fresh produce: risks and opportunities. Epidemiology and Infection, 137(3), 307-315. https://doi.org/10.1017/S0950268808001969

Mackintosh, C. A., \& Hoffman, P. N. (1984). An extended model for transfer of micro-organisms via the hands: differences between organisms and the effect of alcohol disinfection. Journal of Hygiene, 92, 345-355. https://doi.org/10.1017/S0022172400064561 .

Marketrealist. (2014). http://marketrealist.com/2014/11/guide-non-alcoholic-beverage-industry/accessed 4-18-2017.

Marples, R. R., \& Towers, A. G. (1979). A laboratory model for the investigation of contact transfer of micro-organisms. Journal of Hygiene, 82(2), 237-248. https://doi.org/10.1371/journal.pone.0071438

Martinez-Gonzalez, N. E., Hernandez-Herrera, A., Martinez-Chavez, L., Rodriguez-Garcia, M. O., Torres-Vitela, M. R., Mota de la Garza, L., \& Castillo, A. (2003). Spread of bacterial pathogens during preparation of freshly squeezed orange juice. Journal of Food Protection, 66(8), 1490-1494. https://doi.org/10.4315/0362-028X-66.8.1490

Massa, S., Facciolongo, M., Rabasco, E., \& Caruso, M. (1998)> Survival of indicator/pathogenic bacteria in orange soft drink. Food Microbiology, 15, 253-257. https://doi.org/10.1006/fmic.1997.0168

Merry, A. F., Miller, T. E., Findon, G., Webster, C. S., \& Neff, S. P. W. (2001). Touch contamination levels during anesthetic procedures and their relationship to hand hygiene procedures: a clinical audit. British Journal of Anaesthesia, 87, 291-294. https://doi.org/10.1093/bja/87.2.291

Montville, R., Chen, Y., \& Schaffner, D. W. (2002). Risk assessment of hand washing efficacy using literature and experimental data. International Journal of Food Microbiology, 83, 305-313. https://doi.org/10.1016/S0168-1605(01)00666-3

Montville, R., \& Schaffner, D. W. (2003). Inoculum size influences bacterial cross contamination between surfaces. Applied and Environmental Microbiology, 69(12), 7188-7193. https://doi.org/10.1128/AEM.69.12.7188-7193.2003

Moore, C. M., Sheldon, B. W., \& Jaykus, L-E. (2003). Transfer of Salmonella and Campylobacter from stainless steel to Romaine lettuce. Journal of Food Protection, 66(12), 2231-2236. https://doi.org/10.4315/0362-028X-66.12.2231

Nichols, G., Gillespie, I., \& de Louvois, J. (2000). The microbiological quality of ice used to cool drinks and ready-to-eat food from retail and catering premises in the United Kingdom. Journal of Food Protection, 63(1), 78-82. https://doi.org/10.4315/0362-028X-63.1.78 
Panwalker, A. P., \& Fuhse, A. L. (1986). Nosocomial Mycobacterium gordonae pseudoinfection from contaminated ice machines. Infection Control and Hospital Epidemiology, 7(2), 67-70. https://doi.org/10.1017/S0195941700063918

Patrick, D. R. Findon, G., \& Miller, T. E. (1997). Residual moisture determine the level of touch-contact-associated bacterial transfer following hand washing. Epidemiology and Infection, 119(3), 319-325. http://www.jstor.org/stable/4617422

Perez-Rodriguez, F., Valero, A., Carrasco, E., Garcia, R. M., \& Zurera, G. (2008). Understanding and modelling bacterial transfer to foods: a review. Trends in Food Science and Technology, 19(3), 131-144 https://doi.org/10.1016/j.tifs.2007.08.003

Ries, A. A., Vugia, D. J., Beingolea, L., Palacios, A. M., Vasquez, E., Wells, J. G., Baca, N. G., \& Swerdlow, D. L. (1992) Cholera in Piura, Peru: a modern urban epidemic. Journal of Infectious Disease, 166(6), 1429-1433. https://doi.org/10.1093/infdis/166.6.1429

Rocourt, J. B., \& Cossart, P. (1997). Listeria monocytogenes. In: Food Microbiology-Fundamentals and Frontiers, (Doyle, M.P., Beuchat, L.R. \& Montville, T.J. Editors). ASM Press, Washington, DC, pages 337-352.

Rodriguez, A., \& McLandsborough, L. A. (2007). Evaluation of the transfer of Listeria monocytogenes from stainless steel and polyethylene to bologna and American cheese. Journal of Food Protection, 70(3), 600-606. https://doi.org/10.4315/0362-028X-70.3.600

Rose, J. B., \& Slifko, T. R. (1999). Giardia, Cryptosporidium and Cyclospora and their impact on foods: a review. Journal of Food Protection, 62, 1059-1070. https://doi.org/10.4315/0362-028X-62.9.1059

Rusin, P., Maxwell, S., \& Gerba, C. (2002). Comparative surface - to - hand and fingertip - to - mouth transfer efficiency of gram - positive bacteria, gram - negative bacteria, and phage. Journal of Applied Microbiology, 93(4), 585-592. https://doi.org/10.1046/j.1365-2672.2002.01734.x

Sattar, S. A., Springthorpe, S., Mani, S., Gallant, M., Nair, R. C., Scott, E., et al. (2001). Transfer of bacteria from fabrics to hands and other fabrics: development and application of a quantitative method using Staphylococcus aureus as a model. Journal of Applied Microbiology, 90, 962-970. https://doi.org/10.1046/j.1365-2672.2001.01347.x

Scott, E., \& Bloomfield, S. F. (1990). The survival and transfer of microbial contamination via cloth, hands and utensils. Journal of Applied Microbiology, 68(3), 271-278. https://doi.org/10.1111/j.1365-2672.1990.tb02574.x

Shale, K., Jacoby, A., \& Plaatjies, Z. (2006). The impact of extrinsic sources on selected indicator organisms in a typical deboning room. International Journal of Environmental health Research, 16(4), 263-272. https://doi.org/10.1080/09603120600734162

Sheth, N. K., Wisniewski, T. R., \& Franson, T. R. (1988). Survival of enteric pathogens in common beverages: An in vitro study. The American Journal of Gastroenterology, 83(6), 658-660.

Stout, J. E., Yu, V. L., \& Muraca, P. (1985). Isolation of Legionellla pneumophila from the cold water of hospital ice machines: Implications for origin and transmission of the organism. Infection Control and Hospital Epidemiology, 6(4), 141-146. https://doi.org/10.1017/S0195941700062937

USDA (2014). http://www.ers.usda.gov/data-products/cost-of-foodborne-illnesses.aspx accessed 2/28/2017.

WHO, (1997). World Health Organization. Guidelines for drinking-water quality. Surveillance and 436 Control of Community Supplies, 2(3), Available at: http://www.who.int/water_sanitation_health/dwq/gdwqvol32ed.pdf. Accessed on 4-23-2017

Wilson, I. G., Hogg, G. M., \& Barr, J. G. (1997). Microbiological quality of ice in hospital and community. Journal of Hospital Infection, 36(3), 171-180. https://doi.org/10.1016/S0195-6701(97)90192-4

\section{Technical Contribution No. 6670 of the Clemson University Experiment Station.}

\section{Copyrights}

Copyright for this article is retained by the author(s), with first publication rights granted to the journal.

This is an open-access article distributed under the terms and conditions of the Creative Commons Attribution license (http://creativecommons.org/licenses/by/3.0/). 